\title{
Short communication: The effect of raw milk cooling on sensory perception and shelf life of high-temperature, short-time (HTST)-pasteurized skim milk
}

\author{
A. P. Lee, ${ }^{*}$ D. M. Barbano, $\dagger$ and M. A. Drake*1 \\ *Department of Food, Bioprocessing, and Nutrition Sciences, Southeast Dairy Foods Research Center, North Carolina State University, \\ Raleigh 27695 \\ †Department of Food Science, Northeast Dairy Research Center, Cornell University, Ithaca, NY 14850
}

\begin{abstract}
The cooling rate of raw milk may influence sensory properties and pasteurized shelf life. Under the Pasteurized Milk Ordinance for grade A milk, raw milk may be cooled instantaneously by on-farm heat exchangers but is also acceptable if "cooled to $10^{\circ} \mathrm{C}$ or less within four (4) hours of the commencement of the first milking." The objective of this study was to determine the effect of raw milk cooling on consumer perception and shelf life. Raw milk $\left(18-21^{\circ} \mathrm{C}\right)$ was obtained and transported within $1 \mathrm{~h}$ of milking to North Carolina State University (Raleigh). The batch of raw milk was split in 2 portions, and a plate heat exchanger was used to quickly cool one portion to $<6^{\circ} \mathrm{C}$ within $1 \mathrm{~min}$. The second portion was stored in a jacketed bulk tank and slowly cooled over $4 \mathrm{~h}$ to $<10^{\circ} \mathrm{C}$. Milk from 3 consecutive milkings was collected every $12 \mathrm{~h}$, with subsequent milkings added to the previous collections. The bulk milk was kept below $10^{\circ} \mathrm{C}$ while adding milk for the slow cool milk treatment. After $72 \mathrm{~h}$, each whole milk was separated; the skim milk was pasteurized at 73 or $78^{\circ} \mathrm{C}$ for $20 \mathrm{~s}$, homogenized, and held at $4^{\circ} \mathrm{C}$. Difference tests $(\mathrm{n}=75)$ and consumer acceptance tests $(\mathrm{n}=100)$ were conducted to determine if consumers could detect differences among milks. Descriptive analysis and microbial testing for aerobic, psychrotrophic, and psychrotolerant spore counts were conducted through shelf life. The entire experiment was repeated in triplicate. Raw milks averaged $3.3 \log \mathrm{cfu} / \mathrm{mL}$ by aerobic plate count, $<25 \mathrm{cfu} / \mathrm{mL}$ coliforms, somatic cell count of 300,000 cells $/ \mathrm{mL}$, and $3.15 \pm 0.07 \%$ protein. Psychrotolerant spores were not found in the raw milk. Consumers could not detect differences between cooling treatments of the same pasteurization temperature or between different temperatures of the same cooling treatment. Milks reached sensory failure $49 \pm 4 \mathrm{~d}$ on average after
\end{abstract}

Received July 24, 2016.

Accepted September 3, 2016.

${ }^{1}$ Corresponding author: maryanne_drake@ncsu.edu processing, and aerobic counts were between 5 to 7 log $\mathrm{cfu} / \mathrm{mL}$. Cooling treatment had no effect on shelf life. These results suggest that pasteurized milk quality is due to a combination of many factors. Raw milk cooling rate is not the most important factor affecting milk quality when raw milk quality is excellent.

Key words: milk, raw milk, cooling, pasteurization, shelf life, consumer

\section{Short Communication}

Per capita milk consumption has declined steadily from $112.0 \mathrm{~kg}$ of fluid milk consumed in 1975 to 72.1 $\mathrm{kg}$ in 2014, a $35 \%$ decrease (USDA-ERS, 2015). To compete against other beverage offerings that are more shelf stable, fluid milk requires improved product quality and shelf life (Boor, 2001; Caplan and Barbano, 2013). Along with postpasteurization contamination, the major obstacles for milk shelf life are related to bacteria, typically from psychrotrophic bacteria and their heat-resistant enzymes, milk somatic cell enzymes, and native milk proteases (Ma et al., 2000; Santos et al., 2003a,b) and from heat-resistant spore formers (Fromm and Boor, 2004; Huck et al., 2007). Although standards exist for raw milk quality and production of fluid milk in the United States, different farms and processing facilities have different management practices, leading to a wide variation in the overall quality and microbial community of the raw milk (Huck et al., 2007; Masiello et al., 2014). Gram-positive Bacillus spp. and Paenibacillus spp. are among the main microorganisms of concern in raw milk that may limit the shelf life of milk (Meer et al., 1991; Fromm and Boor, 2004; Huck et al., 2007; Ranieri et al., 2009; Masiello et al., 2014). These organisms exist as heat-resistant spores in raw milk that can germinate after pasteurization, which can result in early spoilage of fluid milk by proteolysis or lipolysis (Collins, 1981; Meer et al., 1991; Deeth et al., 2002; Santos et al., 2003a,b; Barbano and Santos, 2006; Huck et al., 2007). The entire milk processing chain is subject to contamination by these microorganisms, from raw milk procurement to final packaging. 
The Pasteurized Milk Ordinance (PMO) regulates the production, packaging, and sale of grade A milk and milk products (FDA, 2013). Included in the PMO are standards for raw milk quality and handling. Raw milk must be cooled within $4 \mathrm{~h}$ to $10^{\circ} \mathrm{C}$ or less from the start of milking, and then to $7^{\circ} \mathrm{C}$ or less within $2 \mathrm{~h}$ after the completion of milking. In addition, subsequent milk collections added to previously collected milk must not raise the temperature of the blended bulk milk above $10^{\circ} \mathrm{C}$ (FDA, 2013). To meet these requirements, dairy producers may use plate heat exchangers to cool the milk rapidly before storage, or they may use bulk tanks to cool the raw milk more slowly. During the slower cooling process, microbial growth may continue, which can affect the subsequent quality of milk pasteurized by HTST processing due to heat-resistant bacteria or enzymes (Muir, 1996; Barbano and Santos, 2006).

Previous studies suggest that the cooling and storage temperature of raw milk may or may not influence the shelf life of raw milk. Guul-Simonsen et al. (1996) reported that instantaneous cooling by heat exchanger to $4^{\circ} \mathrm{C}$ before bulk tank storage reduced bacterial growth compared with a batch cooling process that cooled milk from 35 to $4^{\circ} \mathrm{C}$ in $2.5 \mathrm{~h}$ (Guul-Simonsen et al., 1996). Raw milk stored at $6^{\circ} \mathrm{C}$ averaged $2.9 \mathrm{~d}$ to exceed a psychrotrophic bacteria count of $10^{6} \mathrm{cfu} / \mathrm{mL}$, but storage at $2^{\circ} \mathrm{C}$ increased the time to exceed $10^{6} \mathrm{cfu} / \mathrm{mL}$ to $5 \mathrm{~d}$ on average (Griffiths et al., 1987). A more recent study by O'Connell et al. (2016) reported that storage at 2 or $4^{\circ} \mathrm{C}$ did not significantly affect microbial quality of bulk tank raw milk over $96 \mathrm{~h}$ as long as raw milk entering the bulk tank had very low microbial count. The effects of cooling and storage on raw milk may also affect subsequent pasteurized milk quality and shelf life. Milks pasteurized at $85.2^{\circ} \mathrm{C}$ had higher microbial counts than milks pasteurized at $72.9^{\circ} \mathrm{C}$ with the same hold time following $1,7,14$, or $21 \mathrm{~d}$ postprocessing. The predominant microorganisms found in the pasteurized milks up to $7 \mathrm{~d}$ after processing were from the genus Bacillus, and then from the genus Paenibacillus after 14 d (Ranieri et al., 2009). A case study of a single milk processing plant supported the findings by Ranieri et al. (2009); total bacteria counts for skim, $2 \%$, and whole milk pasteurized at $76.1^{\circ} \mathrm{C}$ for $18.25 \mathrm{~s}$ were lower than those of milk pasteurized at the higher $79.4^{\circ} \mathrm{C}$ temperature with the same hold time for all time points up to $21 \mathrm{~d}$ (Martin et al., 2012). Both of these studies suggested that higher pasteurization temperatures do not necessarily result in longer microbial shelf life of fluid milk. The authors attributed those results to heat germination of spores present in raw milk at increased pasteurization temperatures.

Pasteurization temperature can affect not only microbial quality, but also sensory quality. Thermal treat- ment results in the generation of volatile compounds from denaturation of milk proteins, which subsequently release sulfhydryl, and those formed by nonenzymatic browning reactions (Calvo and de la Hoz, 1992). Sulfhydryl compounds are responsible for cooked/sulfur/eggy characteristics of heated milks, which consumers may not accept (Shipe et al., 1978). Deane et al. (1967) previously reported that adult consumers preferred whole milk pasteurized at $78.9^{\circ} \mathrm{C}$ for $17 \mathrm{~s}$ compared with milk pasteurized at lower $\left(72.2\right.$ and $\left.75.6^{\circ} \mathrm{C}\right)$ and higher $(82.2$ and $85.6^{\circ} \mathrm{C}$ ) temperatures for the same time; children younger than $13 \mathrm{yr}$ were the least discriminating of the pasteurization temperatures. Gandy et al. (2008) examined adult consumer preference for HTST $2 \%$ fat milks pasteurized at $77,79,82$, and $85^{\circ} \mathrm{C}$ for $15 \mathrm{~s}$ and reported that $79^{\circ} \mathrm{C}$ milk was the most acceptable by all consumers. Of these consumers, some consumer clusters were distinguished by acceptability of cooked flavor in the 82 and $85^{\circ} \mathrm{C}$ treatments, while others discriminated against these treatments (Gandy et al., 2008).

The objective of this study was to understand the effect of raw milk cooling rates on shelf life and sensory perception of HTST skim milk. Our hypothesis was that raw milks quickly cooled by a plate heat exchanger before storage would have improved pasteurized shelf life and sensory quality, whereas milks slowly cooled by bulk tank cooling would encourage microbial growth that would limit both shelf life and sensory quality. Skim milk was selected for this study because it is a flavor-sensitive milk matrix compared with higher fat milks in which the presence of fat may mask sensory characteristics. Two different HTST pasteurization temperatures were compared for each cooling treatment to see if consumers could distinguish between cooling or heat treatments.

For this study, $200 \mathrm{~L}$ of raw milk was obtained from the North Carolina State University (NCSU) dairy farm per milking every $12 \mathrm{~h}$ across 3 milkings. The milk was received at 18 to $21^{\circ} \mathrm{C}$ and transported to the NCSU pilot plant facilities in 38-L (10-gallon) sanitized milk cans for cooling. Transportation from the farm to the pilot plant facilities took on average $20 \mathrm{~min}$. Chlorine (200 ppm, Multi-Chlor II, Diversey, Sturtevant, WI) was used to sanitize all equipment. The 3 milkings were collected, cooled, and stored before processing. The TMR feed was held constant throughout the weeks of milk collection to minimize the influence of feed. Continuously recording thermocouple readers (model HH306A, Omega Engineering Inc., Stamford, $\mathrm{CT}$ ) were used to track all temperatures.

At the NCSU pilot plant, the raw milk collected from a milking was blended together before being partitioned for quick-cooling (QC) by a plate heat exchanger (model T4 RGS-16/2, SPX Flow Technology, 
Greensboro, NC) or slow cooling (SC) by a jacketed bulk tank (Precision Stainless Inc., Springfield, MO) with agitator (model XD33VM with 6.0-inch prop, Lightnin, Rochester, NY). For each treatment, $90 \pm$ $3 \mathrm{~kg}$ of milk was stored per milking for a total of 270 $\mathrm{kg}$ per treatment after the third milk collection. For all milkings, the QC milk was cooled to $6^{\circ} \mathrm{C}$ within 1 min by the plate heat exchanger, and then stored in a jacketed bulk tank at $3^{\circ} \mathrm{C}$ with any $\mathrm{QC}$ milk collected previously. The first milking of the SC milk was cooled linearly to $6^{\circ} \mathrm{C}$ across a 4 -h period and stored at $6^{\circ} \mathrm{C}$. For the second and third milk collections, warm raw milk $\left(17-20^{\circ} \mathrm{C}\right)$ was slowly added to the SC bulk tank over the course of $4 \mathrm{~h}$ to prevent the bulk milk from exceeding $10^{\circ} \mathrm{C}$, as stated in the PMO. After the third milk collection, the milks assigned to SC or QC were stored for an additional $48 \mathrm{~h}$ such that the storage time from the first milk collection was no longer than $72 \mathrm{~h}$.

Following storage, the cooled milks were warmed to $50^{\circ} \mathrm{C}$ for separation to skim and cream by a hot bowl centrifugal separator (model SI600E, Agri-Lac, Miami, FL). The skim milk portion was then pasteurized at either 73 or $78^{\circ} \mathrm{C}$ for $20 \mathrm{~s}$ with a Microthermics EHVH pasteurization unit (Microthermics, Raleigh, NC) with a 2-stage homogenizer at $13.8 \mathrm{MPa}$ total pressure with 3.4 MPa on the second stage (GEA Niro Soavi, Parma, Italy). The milks were cooled to $15^{\circ} \mathrm{C}$ by an in-line cooler before packaging in half-gallon light shielding containers (Upstate Niagara Cooperative, Inc., Buffalo, $\mathrm{NY}$ ). The milks were stored at $4^{\circ} \mathrm{C}$ over their shelf life. The order of processing for the cooling treatments was randomized between replications. The entire experiment was repeated in triplicate across a 1-mo period.

Raw milk microbial quality was determined by aerobic plate count (APC, method 990.12; AOAC International, 2012) and coliform count (CC, method 991.14; AOAC International, 2012) using Petrifilm plates (Aerobic Count Plates and Coliform Count Plates, $3 \mathrm{M}$, St. Paul, MN) incubated at $32^{\circ} \mathrm{C}$ for 24 or $48 \mathrm{~h}$, respectively. Psychrotrophic bacteria counts (PBC) were determined (Wehr and Frank, 2004) by plating on plate count agar (BD Difco, Franklin Lakes, NJ) and incubating at $7^{\circ} \pm 1^{\circ} \mathrm{C}$ for $10 \mathrm{~d}$. Raw milk SCC was measured by SomaScope fluorescence flow cytometry (Delta Instruments, Drachten, the Netherlands), drug residue testing was determined by SNAP $\beta$-lactam test kit (Idexx Laboratories Inc., Westbrook, ME), and proximate analyses for fat, protein, and solids were conducted by a Fourier-transform mid-infrared milk analyzer (LactoScope FTIR; Delta Instruments BV). Psychrotrophic spore count (PSC) was evaluated using the methods described by Huck et al. (2007) with modifications. Briefly, raw milks were heated to $80^{\circ} \mathrm{C}$ for 12 min then plated on plate count agar weekly and incubated at $7 \pm 1^{\circ} \mathrm{C}$ for $10 \mathrm{~d}$. Pasteurized milk quality was determined by APC and CC, using the same methods as for raw milk. Samples were plated weekly through shelf life. Pasteurization was confirmed by the Scharer Rapid Visual alkaline phosphatase method (Wehr and Frank, 2004) using a Phos-Kit (Weber Scientific, Hamilton, NJ).

Sensory testing was conducted in accordance with the NCSU Institutional Review Board for the Protection of Human Subjects in Research regulations. A trained panel was used to characterize the flavor profiles of the milks across shelf life and to confirm the end of shelf life by sensory failure. Each panelist ( 4 women, 2 men, ages 21-55 yr) had a minimum of $50 \mathrm{~h}$ of experience evaluating flavor and mouthfeel/texture using the Spectrum method (Meilgaard et al., 2007) and at least $20 \mathrm{~h}$ of previous experience with evaluating sensory properties of fluid milk using an established sensory language (Croissant et al., 2007; McCarthy et al., 2017). Because of the general shelf life objective of this study, 4 attributes were selected for evaluation (sweet aromatic and cooked flavors, sweet taste, and astringency). Milks were evaluated twice a week until the end of shelf life. Samples $(30 \mathrm{~mL})$ were dispensed into lidded $59-\mathrm{mL}$ soufflé cups (Dart Container Corp., Mason, MI) with random 3-digit blinding codes. Samples were prepared with the overhead lights off to prevent light oxidation. Milks were tempered to $10^{\circ} \mathrm{C}$ and evaluated using paper ballots. Each panelist evaluated each milk in duplicate. The trained panel was also used to determine shelf-life failure, which was determined sensorially by spoilage aromas and flavors.

Difference testing with milk consumers was conducted with 4 pairwise comparisons (Pair 1, QC- $73^{\circ} \mathrm{C}$ vs. $\mathrm{QC}-78^{\circ} \mathrm{C}$; Pair 2 , $\mathrm{QC}-73^{\circ} \mathrm{C}$ vs. $\mathrm{SC}-73^{\circ} \mathrm{C}$; Pair 3, $\mathrm{SC}-73^{\circ} \mathrm{C}$ vs. $\mathrm{SC}-78^{\circ} \mathrm{C}$; Pair $4: \mathrm{QC}-78^{\circ} \mathrm{C}$ vs. $\mathrm{SC}-78^{\circ} \mathrm{C}$ ) to determine if consumers could distinguish between cooling treatments or between pasteurization treatments. Testing was conducted by balanced reference duo-trio tests (ASTM E2610; ASTM International, 2012) on the milks $72 \mathrm{~h}$ after processing. A minimum of 50 self-reported milk consumers were recruited from the university community using email listservs for each experimental replicate. Milks $(88 \mathrm{~mL})$ were served in 177-mL Styrofoam cups (Dart Container Corp.) with random 3-digit blinding codes. Each consumer evaluated the 4 pairwise comparisons in one seating that lasted approximately $20 \mathrm{~min}$. Samples were served at $10^{\circ} \mathrm{C}$ and the pairwise duo-trio tests were served in a randomized balanced order. A 2-min enforced rest was implemented between difference tests, and consumers were provided with unsalted crackers and deionized water to cleanse their palates. Panelists were compensated with a food treat after each test and a $\$ 5$ gift card after 
completing 2 separate test sessions. Data were collected by Compusense Cloud software (v6.9, Compusense Inc., Guelph, Canada).

Consumer acceptance testing was also conducted at $4 \mathrm{~d}$ after processing to determine if differences in liking existed. Based on descriptive sensory analysis and consumer difference testing results, 2 samples were selected for consumer acceptance testing, $\mathrm{SC}-73^{\circ} \mathrm{C}$ and SC- $78^{\circ} \mathrm{C}$. Milk consumers $(\mathrm{n}=104)$ were recruited from the NCSU campus. Milks ( $88 \mathrm{~mL}$ ) were dispensed into the same containers and temperature as for difference testing. Panelists were presented samples monadically using a Williams design serving order. Consumers were asked to evaluate appearance, aroma, overall liking, flavor, freshness, cooked flavor, mouthfeel/thickness/ viscosity, and aftertaste on a 9-point hedonic scale where 1 is "dislike extremely" and 9 is "like extremely." Just-about-right questions were asked for sample flavor, mouthfeel/thickness/viscosity, and aftertaste on a 5-point scale, on which 1 was "not nearly enough flavor," "not nearly thick enough," or "much too mild" and 5 was "much too much flavor," "much too thick," or "much too strong," for each question category, respectively. A 2-min enforced rest was used between samples to allow panelists to cleanse their palates using unsalted crackers and deionized water. Last, consumers answered demographic questions that included questions on frequency of milk consumption, frequency of purchase, fat contents consumed, and fat content most often consumed. Panelists were compensated with a $\$ 5$ gift card for participating. Compusense Cloud software was used for data collection.

The study was conducted using a split plot design in which the whole plot factor was cooling treatment and the subplots were 1 of the 2 different pasteurization treatments. Least squares means for cooling and pasteurization treatment effects at each time point were determined using the MIXED procedure in SAS 9.4 (SAS Institute Inc., Cary, NC). Response variables measured were log-transformed APC and PBC and descriptive panel attributes. Proximate analyses and consumer acceptance data were analyzed by ANOVA with means separation (Fisher's least significant difference) using XLSTAT (Version 2015.5.01, Addinsoft, New York, NY). Just-about-right scores were evaluated using chi-squared tests. Critical values for duo-trio results were taken from $\mathrm{Bi}$ (2006). All statistical analyses were performed at the 0.05 significance level.

Fat $(4.15 \pm 0.06 \%)$, protein $(3.12 \pm 0.03 \%)$, and solids $(13.04 \pm 0.13 \%)$ content of the raw milks remained consistent within replications, and no significant differences existed between replications $(P>0.05)$. The initial microbial quality of the raw milk was also assessed before processing. The upper limit in the PMO for grade A raw milk total bacterial count is $5 \log \mathrm{cfu} /$ $\mathrm{mL}(100,000 \mathrm{cfu} / \mathrm{mL})$ for a single producer and $5.48 \mathrm{log}$ $\mathrm{cfu} / \mathrm{mL}(300,000 \mathrm{cfu} / \mathrm{mL})$ when the milk is commingled (FDA, 2013). Milk generally considered as high quality contains less than $4 \log \mathrm{cfu} / \mathrm{mL}(10,000 \mathrm{cfu} / \mathrm{mL})$ by SPC and less than $2 \log \mathrm{cfu} / \mathrm{mL}(100 \mathrm{cfu} / \mathrm{mL})$ by CC (Martin et al., 2012). With these standards, the raw milk used for this study can be considered high quality, indicating that on-farm practices were well controlled and appropriate measures were taken against contamination between milk collection at the farm and treatment at the pilot plant facilities. The raw milks quickly cooled to $6^{\circ} \mathrm{C}$ and then stored at $3^{\circ} \mathrm{C}$ did not differ in microbial counts compared with raw milks slowly cooled to $6^{\circ} \mathrm{C}$ then stored at $6^{\circ} \mathrm{C}$ for $72 \mathrm{~h}: 3.32$ vs. 3.25 $\log \mathrm{APC} ; 3.48$ vs. $3.62 \log \mathrm{PBC}$; and 1.70 vs. $1.72 \log$ CC, respectively $(P>0.05)$. No psychrotolerant spores were detected $(<10$ spores $/ \mathrm{mL}$ ) from any samples. Our results agree with the study by Miller et al. (2015), which examined 33 dairy farms and found that $<1 \%$ of samples had $\geq 10$ psychrotolerant spores $/ \mathrm{mL}$.

Previous studies have addressed the effect of raw milk storage temperature. Gebre-Egziabher et al. (1985) reported that high-quality milks stored at $4^{\circ} \mathrm{C}$ did not have significant increases in SPC and PBC after $3 \mathrm{~d}$ of bulk storage. This finding is consistent with the study by Guul-Simonsen et al. (1996), who compared milks cooled by batch cooling over $1.5 \mathrm{~h}$ and instant cooling/ continuous process; both milks maintained microbial quality up to $3 \mathrm{~d}$. O'Connell et al. (2016) reported that raw milks cooled to $14.5^{\circ} \mathrm{C}$ before bulk storage and stored at $6^{\circ} \mathrm{C}$ had significantly greater total bacterial growth after $48 \mathrm{~h}(3.43 \mathrm{log} \mathrm{cfu} / \mathrm{mL}$ at $0 \mathrm{~h}$ to $3.54 \mathrm{log}$ $\mathrm{cfu} / \mathrm{mL}$ at $72 \mathrm{~h}$ ) with counts reaching $>100,000 \mathrm{cfu} / \mathrm{mL}$ after $96 \mathrm{~h}$ compared with milks stored at 2 or $4^{\circ} \mathrm{C}$. The milks stored at $6^{\circ} \mathrm{C}$ in our study did not have significantly different growth, however, likely because of the shorter incubation time compared with some previous studies and by differing bacterial populations with different growth rates (Muir, 1996). Although raw milk bacterial populations were low in our study, recent evidence also suggests that raw milk microbial tests (i.e., SPC, PBC, CC, laboratory pasteurization count, direct microscopic count, and preliminary incubation count) do not accurately predict the shelf-life performance of pasteurized milks. These tests were all examined for correlation with pasteurized fluid milk shelf life, but the majority showed $\mathrm{R}^{2}$ values $<0.25$, with none greater than 0.45 (Martin et al., 2011).

Aerobic plate counts and psychrotrophic bacteria counts for the pasteurized milk samples stored at $4^{\circ} \mathrm{C}$ during shelf life are shown in Figures 1 and 2, respectively. No significant differences were observed for APC or $\mathrm{PBC}$ among milks at any time point $(P>0.05)$. 
The shelf life of HTST milks is typically dictated by the growth of psychrotrophic microorganisms. Fromm and Boor (2004) reported that off-flavors in milk were associated with the growth of Paenibacillus, Bacillus, and Microbacterium spp. At approximately $6 \mathrm{log} \mathrm{cfu} /$ $\mathrm{mL}$ PBC, spoilage of pasteurized milk can occur due to extracellular enzymatic activity (Muir, 1996). Psychrotrophic bacteria counts for the milks increased from $<2$ $\log \mathrm{cfu} / \mathrm{mL}$ at $\mathrm{d} 28$ to between 4 and $6 \log \mathrm{cfu} / \mathrm{mL}$ at d 35. By d 49, all milks displayed between 6 to $8 \log$ $\mathrm{cfu} / \mathrm{mL}$ PBC (Figure 2). Aerobic plate counts followed a similar trend (Figure 1) as the PBC, with increasing counts beginning at about d 35. Day 49 correlated with the average shelf life of the milks as determined by sensory failure. The extended shelf life of the milks in this study far exceed the typical shelf life of HTST milks, between 2 and 3 weeks; however, Bang et al. (2005) reported that HTST milks from the NCSU dairy spoiled at $42 \mathrm{~d}$ after pasteurization and storage at $4^{\circ} \mathrm{C}$, reflecting the historic cleanliness of the NCSU dairy farm. Varying spoilage patterns in the milk toward the end of shelf life resulted from variation of both APC and PBC. Once all milks from a replicate were deemed spoiled by sensory analysis, microbial data were no longer collected, resulting in fewer data points for the final weeks of shelf life.

The results from our study showed that neither raw milk cooling rate, raw milk storage temperature, nor pasteurization temperature had significant effects on the microbiological quality of the milks, if the microbial quality of the raw milk was excellent (i.e., $<4 \log$ $\mathrm{cfu} / \mathrm{mL} \mathrm{APC}$ and $<2 \log \mathrm{cfu} / \mathrm{mL} \mathrm{CC}$ ) and the spore counts of the raw milk were very low (i.e., $<10$ spores/ $\mathrm{mL}$ ). However, other studies have found differences due to these factors. Ranieri et al. (2009) had previously reported that higher pasteurization temperatures resulted in Paenibacillus spore germination, resulting in increased bacterial numbers during storage for pasteurized $2 \%$ fat milks. The milk used in the current study had no detectable psychrotolerant spore counts. This finding may account for the differences between the reported literature and this study. Longer shelf life observed for low spore count raw milk in the present study is consistent with the effect of spore removal from milk on fluid milk shelf life. Elwell and Barbano (2006) reported that commercially pasteurized raw skim milk had an SPC that exceeded $20,000 \mathrm{cfu} / \mathrm{mL}$ in $29 \mathrm{~d}$ at $4.1^{\circ} \mathrm{C}$, while the same milk that was microfiltered (MF) to remove spores before pasteurization had $90 \%$ of containers with $<20,000 \mathrm{cfu} / \mathrm{mL}$ after $92 \mathrm{~d}$ of shelf life at $4.1^{\circ} \mathrm{C}$ storage. A $3.79 \log$ reduction in total bacteria was achieved by MF and a further $1.84 \mathrm{log}$ reduction was achieved by following MF with minimum pasteurization, resulting in a $5.63 \mathrm{log}$ reduction for the combined process. Similar results for removal of spores from raw milk by MF for minimally pasteurized milk with $2 \%$ fat were reported by Caplan and Barbano (2013). Gravity separation has also been demonstrated as an approach to remove spores from raw milk (Caplan et al., 2013; Geer and Barbano, 2014). Future studies should examine the effect of alternative spore removal technologies (e.g., spore removal by centrifugation or gravity separation) on fluid milk shelf life, sensory properties, and the cost of processing.

Trained panelists could not detect differences in sensory attributes intensities between quick cooled and slow cooled milk at any time point $(P>0.05$; results not shown). Small but significant differences $(P<0.05)$ were noted for $78^{\circ} \mathrm{C}$ pasteurized milks compared with $73^{\circ} \mathrm{C}$ pasteurized milks in cooked and sweet aromatic flavor intensities at $\mathrm{d} 3$ and 7 (3.4 vs. 3.1 and 2.0 vs. 1.7 ), but not at subsequent time points. Differences were not detected between $78^{\circ} \mathrm{C}$ and $73^{\circ} \mathrm{C}$ pasteurized milks for other attributes $(P>0.05$; results not shown). Overall aroma intensity and sweet aromatic and cooked flavors decreased with storage time for all milks $(P<0.05$; results not shown). Sensory failure for milks occurred at $49 \pm 4 \mathrm{~d}$ after processing and was not statistically different among treatments $(P<0.05)$. For all replicates, no significant differences were detected for the 4 paired comparisons (Table 1), indicating that consumers were unable to differentiate between cooling treatments or between pasteurization temperatures at $4 \mathrm{~d}$ postprocessing $(P>0.05)$. Although difference tests revealed that consumers could not detect differences between milks, trained panelists detected small differences in cooked and sweet aromatic flavors between 73 and $78^{\circ} \mathrm{C}$ pasteurized milks through d 7 . As such, 2 milks $\left(\mathrm{SC}-73^{\circ} \mathrm{C}\right.$ and $\mathrm{SC}-78^{\circ} \mathrm{C}$ ) were subjected to consumer acceptance testing. Consumer acceptance testing $(\mathrm{n}=104)$ at $4 \mathrm{~d}$ postprocessing detected no differences in any attribute $(P>0.05)$. Liking for all attributes (overall, appearance, aroma, flavor, freshness, and mouthfeel) was at parity and was between "liked slightly" (6) and "liked moderately" (7) on the 9-point hedonic scale.

The trained panel results suggest that pasteurization temperature had a greater effect on sensory perception than raw milk cooling rate, but the majority of consumers were unable to differentiate between skim milks pasteurized at either 73 or $78^{\circ} \mathrm{C}$ by either difference or acceptance testing. These results differ from the results reported by Gandy et al. (2008), who reported that $2 \%$ fat milks pasteurized at $79^{\circ} \mathrm{C}$ were significantly more liked than milks pasteurized at 77,82 , or $85^{\circ} \mathrm{C}(6.7$ on a 9-point hedonic scale compared with $6.1,6.1$, and 5.9 , respectively) after $6 \mathrm{~d}$ of storage. Consumer clusters were distinguished by liking or disliking of cooked 

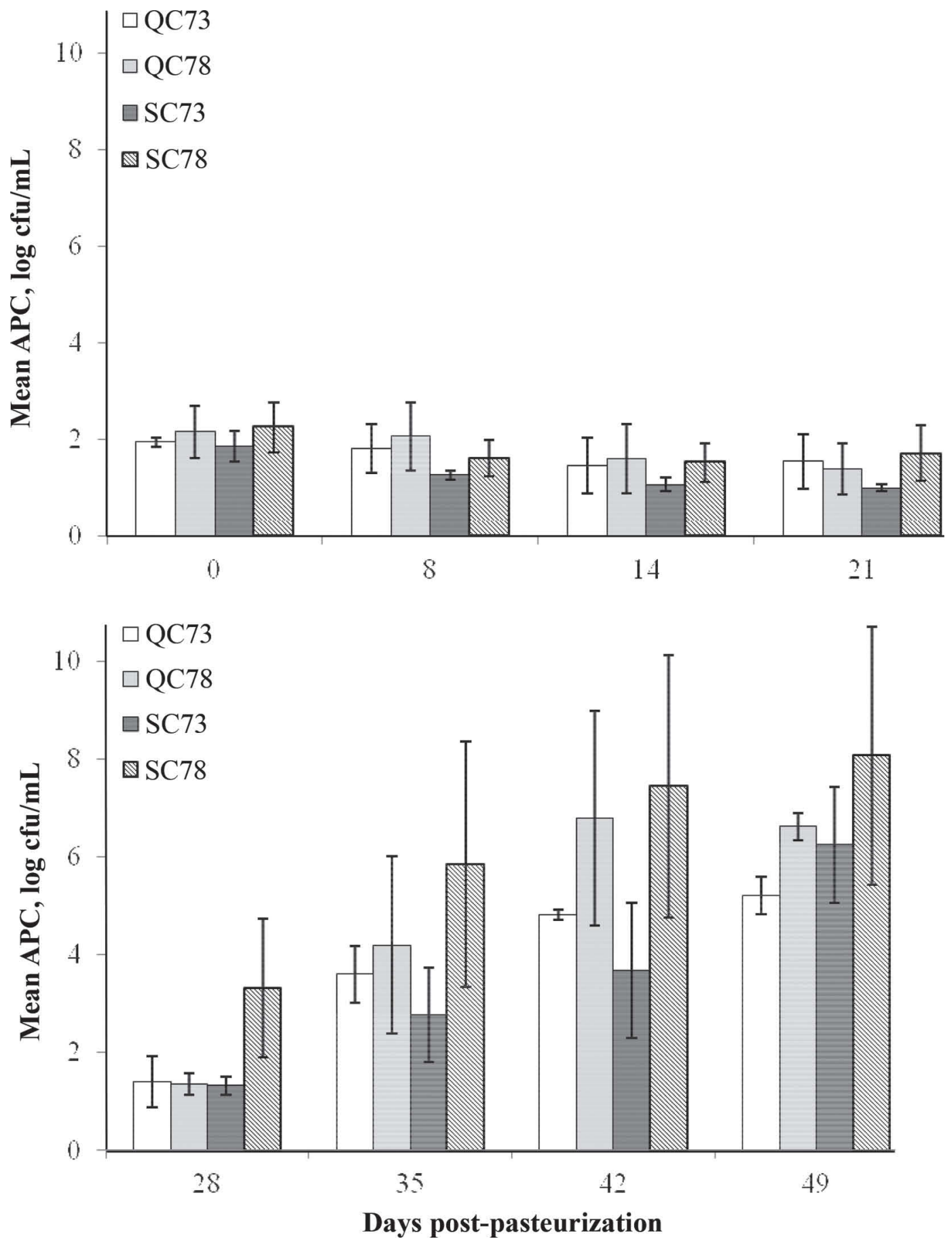

Figure 1. Aerobic plate count (APC) of quick-cooled (QC) and slow-cooled (SC) milk pasteurized at $73^{\circ} \mathrm{C}$ or $78^{\circ} \mathrm{C}$ and stored at $4^{\circ} \mathrm{C}$ through shelf life. The data represent the mean of 3 independent replicates. Bars represent the mean $\pm 1 \mathrm{SD}$ for each treatment.

flavor (Gandy et al., 2008). Chapman and Boor (2001) also reported that children 6 to 11 yr old preferred HTST milk over ultrapasteurized and UHT milks. Ultra-pasteurized and UHT milks have prominent cooked characteristics (Chapman et al., 2001; Clare et al., 2005), which can influence consumer acceptance.
As previously mentioned, degradation by extracellular enzymatic activity from psychrotrophic bacteria and native milk enzymes associated with high milk SCC can result in the end of shelf life for fluid milk. If the cooling rate of raw milk influenced microbial numbers and subsequent enzyme production, then milks would 
Table 1. Consumer difference test results for pair-wise comparisons between cooling treatments and pasteurization temperatures at $4 \mathrm{~d}$ postprocessing

\begin{tabular}{|c|c|c|c|c|c|c|}
\hline \multirow[b]{2}{*}{ Pair-wise comparison $^{1}$} & \multicolumn{2}{|c|}{$\begin{array}{c}\text { Replicate } 1 \\
(\mathrm{n}=75)\end{array}$} & \multicolumn{2}{|c|}{$\begin{array}{c}\text { Replicate } 2 \\
(\mathrm{n}=77)\end{array}$} & \multicolumn{2}{|c|}{$\begin{array}{c}\text { Replicate } 3 \\
(\mathrm{n}=51)\end{array}$} \\
\hline & $\begin{array}{l}\text { No. } \\
\text { correct }\end{array}$ & Difference? & $\begin{array}{c}\text { No. } \\
\text { correct }\end{array}$ & Difference? & $\begin{array}{l}\text { No. } \\
\text { correct }\end{array}$ & Difference? \\
\hline $\mathrm{QC}-73^{\circ} \mathrm{C}$ vs. $\mathrm{QC}-78^{\circ} \mathrm{C}$ & 33 & $\mathrm{No}$ & 40 & No & 28 & No \\
\hline QC $-73^{\circ} \mathrm{C}$ vs. $\mathrm{SC}-73^{\circ} \mathrm{C}$ & 36 & No & 37 & No & 28 & No \\
\hline SC- $73^{\circ} \mathrm{C}$ vs. SC- $78^{\circ} \mathrm{C}$ & 39 & No & 31 & No & 29 & No \\
\hline
\end{tabular}

${ }^{1} \mathrm{SC}=$ slow-cooled; $\mathrm{QC}=$ quick-cooled. Pasteurization temperature $=73^{\circ}$ or $78^{\circ} \mathrm{C}$.

be expected to exhibit greater proteolytic and lipolyticrelated flavors earlier in the shelf life (Barbano and Santos, 2006). However, neither of these types of flavors was found in the milks before gross spoilage of all treatments, indicating that either the microbial growth was not sufficient to generate significant amounts of enzymes in the slow-cooled milks before the quick-cooled milks or that the microbial population in the milks did not produce degradative enzymes. No differences in raw milk microbial counts were detected between the slow or quick-cooled milks before pasteurization; therefore, bacterial growth and population of the slow-cooled milk were likely not sufficient for producing differences in pasteurized shelf life. The microorganisms in the raw milk were not identified. As such, it is unknown if the bacterial populations in the raw milks were capable of producing proteolytic and/or lipolytic enzymes. Previous research has used molecular subtyping (Huck et al., 2007; Masiello et al., 2014) and sequence analysis (De Jonghe et al., 2010) to identify spore-forming bacteria, mainly Bacillus and Paenibacillus spp., in raw milk and fluid milk processing systems. These bacteria have been shown to be capable of producing degradative enzymes (Fromm and Boor, 2004; De Jonghe et al., 2010). On-

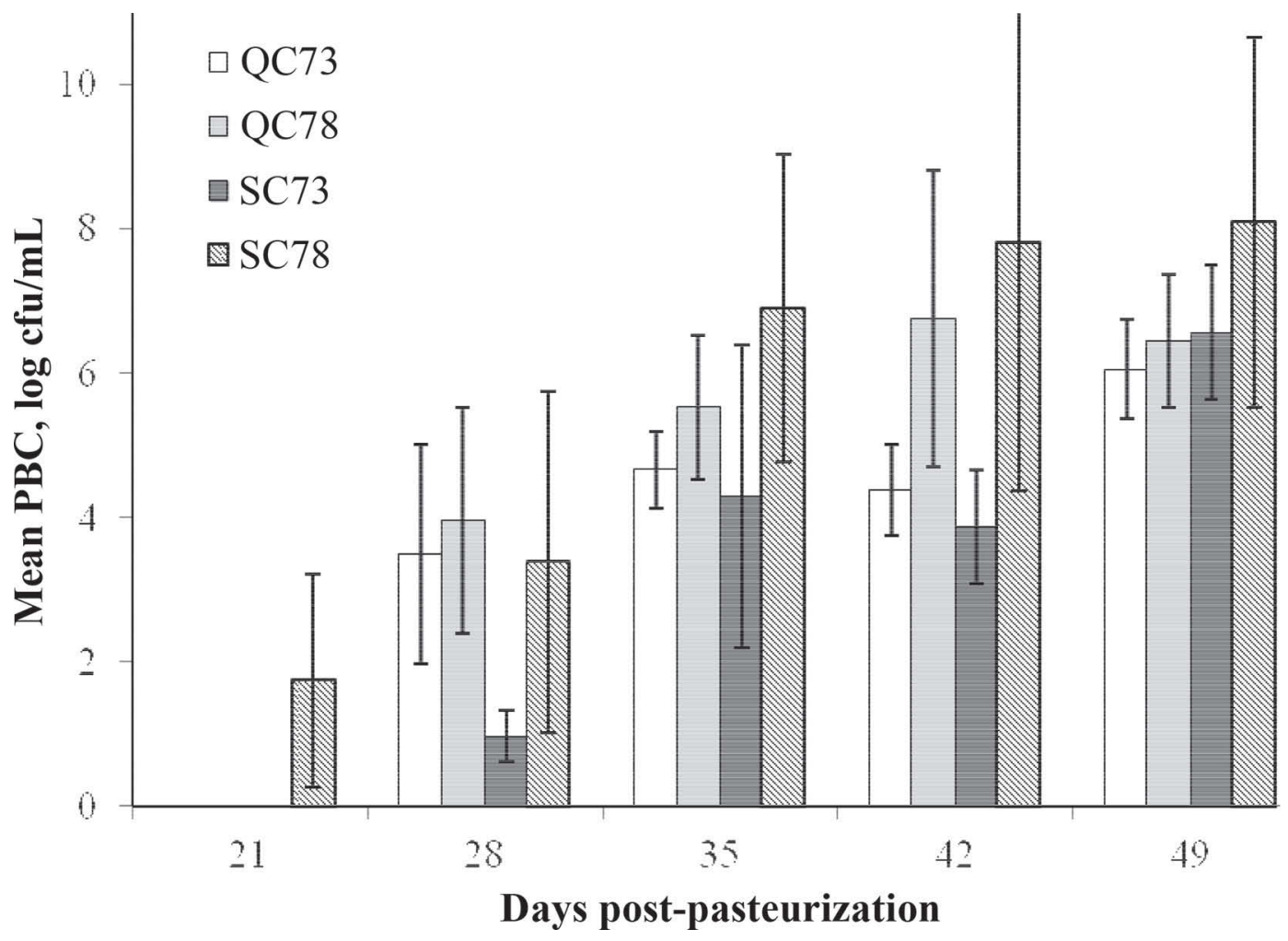

Figure 2. Psychrotrophic bacteria count (PBC) of quick-cooled (QC) and slow-cooled (SC) milk pasteurized at $73^{\circ} \mathrm{C}$ or $78^{\circ} \mathrm{C}$ and stored at $4^{\circ} \mathrm{C}$ through shelf life. The data represent the mean of 3 independent replicates. Bars represent the mean \pm 1 SD for each treatment. 
farm practices can influence the levels of spores found in raw milk, which can also contribute to postprocessing contamination (Huck et al., 2007; Masiello et al., 2014; Miller et al., 2015). The data from this study show that the cooling temperatures and rates used in our study of high microbial quality raw milk does not affect microbial growth and subsequent shelf life. Instead, other on-farm practices that control microbial contamination of raw milk should be considered for their effect on pasteurized milk shelf life and quality.

The temperatures and rate of raw milk cooling used in our study did not affect the sensory characteristics or the shelf life of pasteurized skim milk. Instead, we found that the factor with the greatest effect on sensory perception was pasteurization temperature, but only slight differences were noted by a trained panel; consumers were unable to distinguish between pasteurization temperatures. These results validate the processing standards in the PMO for the cooling of raw milk and reiterate the importance of quality management from farm practices through processing and packaging. Future studies should examine alternative methods of microbial and spore removal from raw milk combined with minimum time and temperature for pasteurization. The effect of raw milk cooling rate should be examined with raw milks nearing the upper quality limits in the PMO.

\section{ACKNOWLEDGMENTS}

This project was supported in part by the National Dairy Council (Rosemont, IL). The use of tradenames does not imply endorsement nor lack of endorsement by those not mentioned.

\section{REFERENCES}

AOAC International. 2012. Official Methods of Analysis. 19th ed. AOAC International, Gaithersburg, MD.

ASTM International. 2012. ASTM E2610-08(2011): Standard test method for sensory analysis - Duo-trio test. ASTM International, West Conshohocken, PA. http://www.astm.org/Standards/E2610.

Bang, W., D. Clare, G. Cartwright, and M. A. Drake. 2005. Impact of a piggyback heat exchanger system on the shelf-life of pasteurized fluid milk. Abstract 71A-29 in Proc. 66th Annual Meeting of the Institute of Food Technologists, New Orleans, LA. Institute of Food Technologists, Chicago, IL.

Barbano, D. M., and M. V. Santos. 2006. Influence of raw milk quality on fluid milk shelf life. J. Dairy Sci. 89(E. Suppl):E15-E19.

Bi, J. 2006. Standard discrimination tests. Pages 10-11 in Sensory Discrimination Tests and Measurements. 1st ed. Blackwell Pub., Ames, IA.

Boor, K. J. 2001. Fluid dairy product quality and safety: Looking to the future. J. Dairy Sci. 84:1-11.

Calvo, M., and L. de la Hoz. 1992. Flavour of heated milks. A review. Int. Dairy J. 2:69-81.

Caplan, Z., and D. M. Barbano. 2013. Shelf life of pasteurized microfiltered milk containing $2 \%$ fat. J. Dairy Sci. 96:8035-8046.
Caplan, Z., C. Melilli, and D. M. Barbano. 2013. Gravity separation of fat, somatic cells, and bacteria in raw and pasteurized milks. J. Dairy Sci. 96:2011-2019.

Chapman, K. W., and K. J. Boor. 2001. Acceptance of $2 \%$ ultrapasteurized milk by consumers, 6 to 11 years old. J. Dairy Sci. 84:951-954.

Chapman, K. W., H. T. Lawless, and K. J. Boor. 2001. Quantitative descriptive analysis and principal component analysis for sensory characterization of ultrapasteurized milk. J. Dairy Sci. 84:12-20.

Clare, D. A., W. S. Bang, G. Cartwright, M. A. Drake, P. Coronel, and J. Simunovic. 2005. Comparison of sensory, microbiological, and biochemical parameters of microwave versus indirect UHT fluid milk skim milk during storage. J. Dairy Sci. 88:4172-4182.

Collins, E. B. 1981. Heat resistant psychrotrophic microorganisms. J. Dairy Sci. 64:157-160.

Croissant, A. E., S. P. Washburn, L. L. Dean, and M. A. Drake. 2007. Chemical properties and consumer perception of fluid milk from conventional and pasture-based production systems. J. Dairy Sci. 90:4942-4953.

De Jonghe, V., A. Coorevits, J. De Block, E. Van Coillie, K. Grijspeerdt, L. Herman, P. De Vos, and M. Heyndrickx. 2010. Toxinogenic and spoilage potential of aerobic spore-formers isolated from raw milk. Int. J. Food Microbiol. 136:318-325.

Deane, D., J. Chelesvig, and W. Thomas. 1967. Pasteurization treatment and consumer acceptance of milk. J. Dairy Sci. 50:1216-1220.

Deeth, H. C., T. Khusniati, N. Datta, and R. B. Wallace. 2002. Spoilage patterns of skim and whole milks. J. Dairy Res. 69:227-241.

Elwell, M. W., and D. M. Barbano. 2006. Microfiltration in the processing of extended shelf life skim milk. J. Dairy Sci. 89(ESuppl.):E20-E30.

FDA. 2013. Standards for grade "A" milk and milk products. Pages 31-34 in Grade "A" Pasteurized Milk Ordinance. US Department of Health and Human Services, Public Health Service, Washington, DC.

Fromm, H., and K. J. Boor. 2004. Characterization of pasteurized fluid milk shelf-life attributes. J. Food Sci. 69:M207-M214.

Gandy, A. L., M. W. Schilling, P. C. Coggins, C. H. White, Y. Yoon, and V. V. Kamadia. 2008. The effect of pasteurization temperature on consumer acceptability, sensory characteristics, volatile compound composition, and shelf-life of fluid milk. J. Dairy Sci. 91:1769-1777.

Gebre-Egziabher, A., A. Cheong, G. Blankenagel, and E. Humbert. 1985. Extended storage of raw milk. I. Effect on microbiological quality. Can. Inst. Food Sci. Technol. 18:247-250.

Geer, S. R., and D. M. Barbano. 2014. The effect of immunoglobulins and somatic cells on the gravity separation of fat, bacteria, and spores in pasteurized whole milk. J. Dairy Sci. 97:2027-2038.

Griffiths, M. W., J. D. Phillips, and D. D. Muir. 1987. Effect of lowtemperature storage on the bacteriological quality of raw milk. Food Microbiol. 4:285-291.

Guul-Simonsen, F., P. S. Christiansen, D. Edelsten, J. R. Kristiansen, N. P. Madsen, E. W. Nielsen, and L. Petersen. 1996. Cooling, storing and quality of raw milk. Acta Agric. Scand. A Anim. Sci. 46:105-110.

Huck, J. R., B. H. Hammond, S. C. Murphy, N. H. Woodcock, and K. J. Boor. 2007. Tracking spore-forming bacterial contaminants in fluid milk-processing systems. J. Dairy Sci. 90:4872-4883.

Ma, Y., C. Ryan, D. M. Barbano, D. M. Galton, M. A. Rudan, and K J. Boor. 2000. Effects of somatic cell count on quality and shelf-life of pasteurized fluid milk. J. Dairy Sci. 83:264-274.

Martin, N. H., M. L. Ranieri, S. C. Murphy, R. D. Ralyea, M. Wiedmann, and K. J. Boor. 2011. Results from raw milk microbiological tests do not predict the shelf-life performance of commercially pasteurized fluid milk. J. Dairy Sci. 94:1211-1222.

Martin, N. H., M. L. Ranieri, M. Wiedmann, and K. J. Boor. 2012. Reduction of pasteurization temperature leads to lower bacterial outgrowth in pasteurized fluid milk during refrigerated storage: A case study. J. Dairy Sci. 95:471-475.

Masiello, S. N., N. H. Martin, R. D. Watters, D. M. Galton, Y. H. Schukken, M. Wiedmann, and K. J. Boor. 2014. Identification of dairy farm management practices associated with the presence 
of psychrotolerant sporeformers in bulk tank milk. J. Dairy Sci. 97:4083-4096.

McCarthy, K. S., K. Lopetcharat, and M. A. Drake. 2017. Milkfat threshold determination and the effect of milkfat content on consumer preference of fluid milk. J. Dairy Sci. http://dx.doi. org/10.3168/jds.2016-11417.

Meer, R., J. Baker, F. Bodyfelt, and M. Griffiths. 1991. Psychrotrophic bacillus spp. in fluid milk products: A review. J. Food Prot. 54:969-979.

Meilgaard, M., G. V. Civille, and B. T. Carr. 2007. Descriptive analysis techniques. Pages 173-188 in Sensory Evaluation Techniques. 4th ed. CRC Press, Boca Raton, FL

Miller, R. A., D. J. Kent, K. J. Boor, N. H. Martin, and M. Wiedmann. 2015. Different management practices are associated with mesophilic and thermophilic spore levels in bulk tank milk. J. Dairy Sci. 98:4338-4351.

Muir, D. 1996. The shelf-life of dairy products: 1. Factors influencing raw milk and fresh products. J. Soc. Dairy Technol. 49:24-32.

O'Connell, A., P. L. Ruegg, K. Jordan, B. O'Brien, and D. Gleeson. 2016. The effect of storage temperature and duration on the microbial quality of bulk tank milk. J. Dairy Sci. 99:3367-3374.

Ranieri, M. L., J. R. Huck, M. Sonnen, D.M. Barbano, and K. J. Boor. 2009. High temperature, short time pasteurization temperatures inversely affect bacterial numbers during refrigerated storage of pasteurized fluid milk. J. Dairy Sci. 92:4823-4832.

Santos, M. V., Y. Ma, and D. M. Barbano. 2003b. Effect of somatic cell count on proteolysis and lipolysis in pasteurized fluid milk during shelf-life storage. J. Dairy Sci. 86:2491-2503.

Santos, M. V., Y. Ma, Z. Caplan, and D. M. Barbano. 2003a. Sensory threshold of off-flavors caused by proteolysis and lipolysis in milk. J. Dairy Sci. 86:1601-1607.

Shipe, W. F., R. Bassette, D. D. Deane, W. L. Dunkley, E. G. Hammond, W. J. Harper, D. H. Kleyn, M. E. Morgan, J. H. Nelson, and R. A. Scanlan. 1978. Off flavors of milk: Nomenclature, standards, and bibliography. J. Dairy Sci. 61:855-869.

USDA-ERS (Economic Research Service). 2015. Food availability per capita data system. USDA, Economic Research Service. Accessed August 20, 2015. http://www.ers.usda.gov/data-products/dairydata.aspx.

Wehr, H. M., and J. F. Frank. 2004. Microbiological count methods. Coliform and other indicator bacteria. Alkaline phosphatase methods. Pages 153-226, 341-362 in Standard Methods for the Examination of Dairy Products. 17th ed. Am. Pub. Health Assoc., Washington, DC. 